\title{
Double Roles of Married Working Women in Indonesia: For Better or for Worse?
}

\author{
Deniey A. Purwanto* \\ *Department of Economics, Faculty of Economics and Management, IPB University.
}

Received: 19 August 2021 Accepted: 01 November 2021 Published: 14 December 2021

\begin{abstract}
SDGs 2030 have at least two goals that strongly converged to gender equality of pay, gender equality (Goal 5), and decent work and economic growth (Goal 8). Marital status argued to have significant contribution in gender inequality of pay and the root of female wage penalty. The argument associated with traditional family division of labour, where men responsible for family breadwinner and women for family caregiver. We examine this argument in Indonesia experiences with additional feature of multiple breadwinner models in the family. Utilizing Indonesian National Labour Force Survey of 2015 of more than 150.000 workers, our twofold regression compatible Oaxaca-Blinder decomposition analysis confirmed the existence of statistically significant gender wage gap even when controlling for the human capital investment, family division of labour, institutional instrument and discrimination. Our findings suggest that married women tend to take a double role than married men, being family breadwinner as well as family caregiver. In that double role model, wage rate is highest among working women and marriage wage penalty died out. Unfortunately, gender wage gap and wage discrimination persisted. While the role of minimum wage as current nominal institutional labour market instrument still trivial, other factors must also be addressed toward gender equality of pay and more efficient labour market.
\end{abstract}

JEL Codes: J24, J31, J46, J71

Keywords: wage differential decomposition, gender wage gap, family breadwinner, marriage wage premium, minimum wage.

This manuscript is part of a publicly defended PhD thesis of Georg-August Universität Göttingen, Germany. 


\section{INTRODUCTION}

Equal pay is a labour right that recognizes the equality of wage structure among individual in the labour market. The right is based on pay equity and pay equality principles. The most intensive demographic perspective on these principles is gender equality of pay. Despite the principles were already introduced more than century ago in the Peace Treaty of Versailles, recent and future development still recognise gender equality of pay as essential factor of development. In Sustainable Development Goals (SDGs) 2030, there are at least two goals are converged to gender equality of pay, Goal 5 Gender Equality and Goal 8 Decent Work and Economic Growth. Gender wage gap commonly used as the measurement of gender equality of pay ${ }^{1}$.

Despite global trends show narrowing gender wage gap in recent years (Blau \& Kahn, 2016; OrtizOspina \& Roser, 2018), many countries are still dealing with the gap nearly a century after the global recognition of equal pay. The problem persists for the reasons of productivity and non-productivity relevant factors. The former attributes to human capital investment factors, such as education, specialization and training. Whilst the latter attribute to factors like undervaluing of female dominated jobs (Leuze \& Strauß, 2016; Suleman \& Figueiredo, 2018), gender occupational segregation (Perales, 2013; Fuchs, 2016; Blau \& Kahn, 2017), discrimination (Ahmed, 2014; Mihăilă, 2016), and family breadwinner socio-cultural paradigm (Lim, 2015; Bear \& Glick, 2017; and Parry \& Segalo, 2017). On the latter cases, gender wage gap lead to the discussion of roles of married women in the family and its contribution to gender inequality of pay. .

Narrowing gender wage gap and diminishing marriage wage penalty required effective policy instruments. The empirical selections is numerous; including mainstreaming strategies, legal provisions, institutional arrangement, wage determination, requirement and audit, to collective agreement ${ }^{2}$. The effectiveness of the selected instrument might be another story. It will depend on the development of labour market and current socioeconomic condition within each nation. The effort on narrowing the gender wage gap might also require an integrated program aims at the institutional aspect, the workers and the employers. For a developing country, such integrated program might less visible to develop at least in the short run. Exercising established policy instrument is an alternative option. Compared to fiscal instruments, which are frequently limited for developing countries, minimum wage could be an alternative. Recent studies on the effectiveness of minimum wage in narrowing gender wage gap are infinite, to name a few of recent work including Bargain, Doorley \& Van Kern (2016), David, Manning \& Smith (2016), and Majchrowska \& Strawiński (2018). Only a few are explicitly

\footnotetext{
${ }^{1}$ Gender wage gap commonly associated to the achievement of SDGs targets, including Target 5.1. End discriminations against women and girls, and Target 8.5. Full employment and decent work with equal pay.

2 e.g. see: Foubert (2010); Oelz, Olney \& Tomel (2013); Erickson (2015); Kahn (2015); Rubery \& Koukiadaki (2016); and Huffman, King \& Reichelt (2017).
} 
studied for the case of Indonesia as in Fitriani (2013), Taniguchi \& Tuwo (2014), and Driemeier, Rijkers \& Waxman (2015).

Data from The Global Gender Gap Report show that Indonesia gender inequality of pay are relatively high and deteriorating for the last few years (Figure 1). Thus, narrowing the gap for Indonesia pose several importance. First, Indonesia is one of ASEAN countries that simultaneously implementing single market of ASEAN Economic Community (AEC) by the end of 2015. Consequently, Indonesia is facing crucial challenges toward ASEAN integrated labour market. Secondly, Indonesia is also committing in mainstreaming Sustainable Development Goals 2030 (SDGs 2030). Goal Eight of SDGs is promoting decent work and economic growth which targeting full and productive employment and decent work for all women and men in 2030. This goal explicitly and implicitly raises and strengthens the important of narrowing gender wage gap.

\section{Figure 1. Wage Equality for Similar Work of ASEAN+3 Countries, 2008-2015}

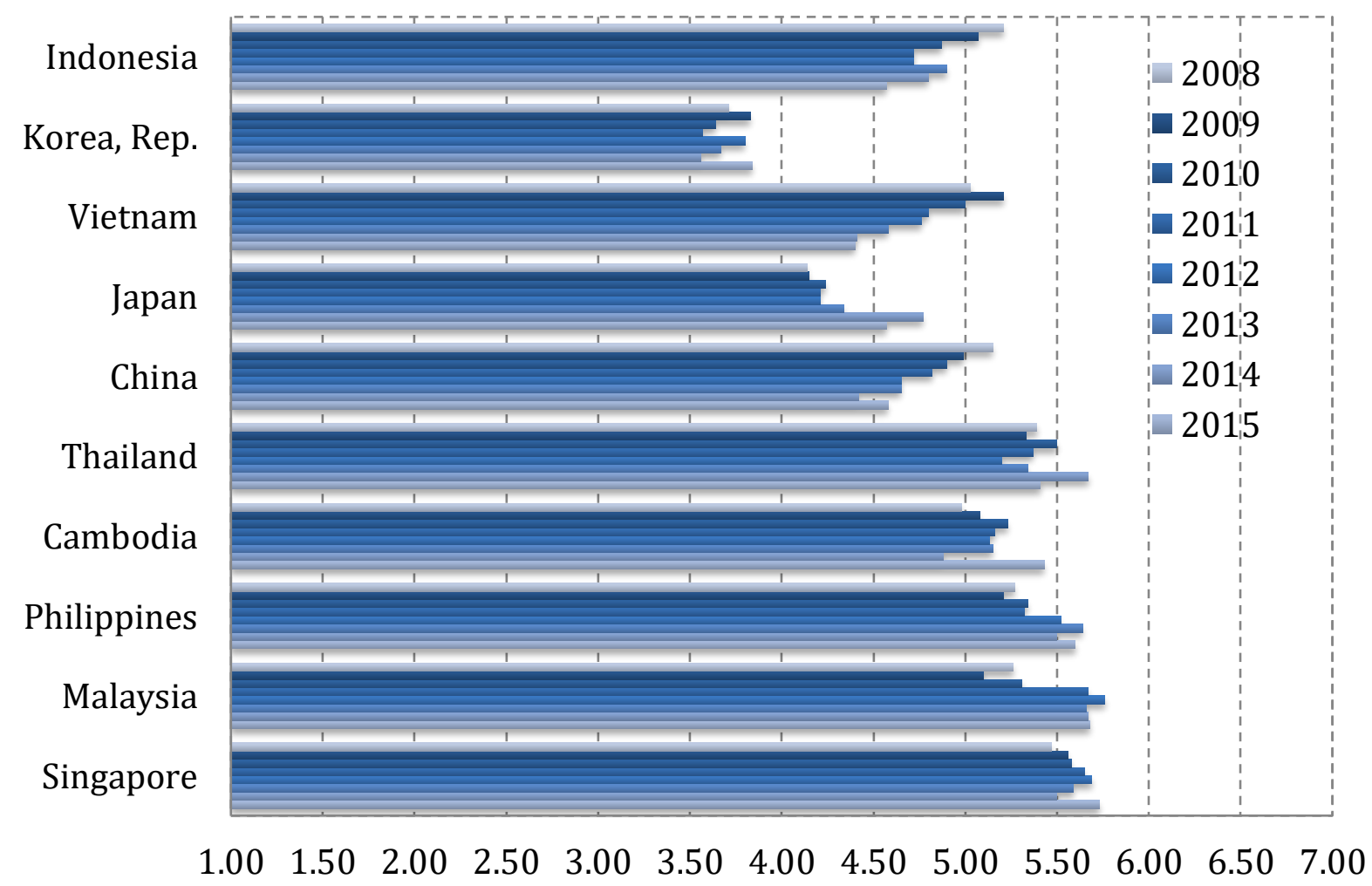

Note: ILO survey is asking whether it is equal or not on the range of 1-7, $1=$ Not at all, significantly below those of men; 7 = fully, equal to those of men.

Source: The Global Gender Gap Report, World Economic Forum, 2015, reproduced.

Thirdly, Indonesia has long history of minimum wage legislation. It developed from a national discretionary policy instrument in 80 's into compulsory sub provincial wage references in recent years. These development resulted from many factors including international pressure in the late 80's, decentralization of minimum wage legislations in the late 90's and strengthening of labour unions role in the tripartite system (Sugiyarto \& Endriga, 2008). Presently, it is legislated in two strands of 
instruments. The first one legislated as sub national level (i.e. provincial and sub provincial) and the other legislated for sectoral level in some provinces. Considering those scope, minimum wages could be an option toward more gender equality of pay.

Utilizing twofold regression compatible Blinder-Oaxaca decomposition method based-on individual workers of National Labour Force Survey (SAKERNAS) 2015 dataset, this paper complement the literatures in, i.e.: (i) examine the extend of contributing factors of gender wage gap (i.e. human capital investment, demographics characteristics, minimum wage, occupational segregation, and discrimination); and (ii) examine the extend of family division of labour on gender wage gap and marriage premium and penalty; The remainder of this paper is structured as followed: Section 2 provides a discussion of relevant literature; Section 3 explains the data in use and estimation strategy; Section 4 deals with the presentation and interpretation of the empirical results; and finally, Section 5 concludes.

\section{METHODS}

Our analysis is based on the Indonesian National Labour Force Survey (INLFS), or also acknowledged as SAKERNAS. The survey collects data at the household and individual level, including individual characteristics, earnings, activities related to employment status, information on primary and secondary jobs, and others such as working hours and tenure. We use second round of the 2015 wave with more than 200,000 working individuals, including self-employed individuals. The advantage of SAKERNAS compared to other datasets, such as the Indonesian Family Life Survey (IFLS), is that it covers all regions in Indonesia, consist of 34 provinces and 511 sub provinces. Our sample is intentionally made up of individuals who are working and between the ages of 15 to 65 years old to ensure that child or elderly are not included. Although many people continue to work beyond the age of 65 , we use this cut off accordingly to the official retirement age for public worker in Indonesia.

Estimation model is based-on a Mincerian earnings function with additional variables considering theoretical and empirical literatures, including human capital investment, family division of labour, institutional of labour market, segregation and discrimination. We estimate following specification:

$$
\ln w_{i(F, M)}=a_{0}+a_{1 j} L_{i(F, M)}^{j}+a_{2 j} H_{i(F, M)}^{j}+a_{3 j} C_{i(F, M)}^{j}+a_{3 j} O_{i(F, M)}^{j}+a_{4} I_{m}+\varepsilon_{i}
$$

where log of nominal individual wage $\left(\mathrm{w}_{\mathrm{i}}\right)$ of female $(\mathrm{F})$ or male $(\mathrm{M})$ worker groups, determine by multiple contributing factors, including individual characteristic $(\mathrm{L})$, human capital investment $(\mathrm{H})$, working condition $(\mathrm{C})$, occupational choice $(\mathrm{O})$ and institutional instruments of labour market (I). 
Within each factor, multiple relevant explanatory variables are exercised ${ }^{3}$. Variables detail and measurement will be elaborate in the next section.

The next step is the decomposition analysis. Throughout the decomposition analysis, we seek to examine the extent of gender wage gap and its contributing factor. We opt Oaxaca-Blinder decomposition method (Oaxaca, 1973; Blinder, 1973) for the analysis. Oaxaca-Blinder decomposition method combines human capital theory and discrimination theory in explaining earnings differential. The idea is to put together all possible contributing factors and contrast the results of particular groups to their corresponding groups through a decomposition process. In this case between female workers and male workers. By assuming that wage determination is separable in observable and unobservable characteristics, equation (2.1.) can be generalized as follows:

$$
w_{g}=\beta_{g} X+\varepsilon_{g}, \quad E\left(\varepsilon_{g}\right)=0 \quad g \epsilon(f, m)
$$

Where $(w)$ is the natural logarithm of individual wages, $(X)$ is a vector of explanatory variables, $(\square)$ contains the slope of the parameters and the intercept, and $(\varepsilon)$ is the error term. The subsequent step is then to measure the means linear prediction of wage differences between female workers $(F)$ and male workers $(M)$ through the following equation:

$$
R=E\left(w_{F}\right)-E\left(w_{M}\right)
$$

and because:

$$
\mathrm{E}\left(\mathrm{w}_{\mathrm{g}}\right)=\mathrm{E}\left(\mathrm{X}_{\mathrm{g}}^{\prime} \hat{\beta}_{\mathrm{g}}+\varepsilon_{\mathrm{g}}\right)=\mathrm{E}\left(\mathrm{X}_{\mathrm{g}}^{\prime} \hat{\beta}_{\mathrm{g}}\right)+\mathrm{E}\left(\epsilon_{\mathrm{g}}\right)=\mathrm{E}\left(\mathrm{X}_{\mathrm{g}}\right)^{\prime} \widehat{\beta}_{\mathrm{g}}
$$

the mean wage difference between these two groups (4) can be computed as:

$$
\mathrm{R}=\mathrm{E}\left(\mathrm{w}_{\mathrm{F}}\right)-\mathrm{E}\left(\mathrm{w}_{\mathrm{M}}\right)=\mathrm{E}\left(\mathrm{X}_{\mathrm{F}}\right)^{\prime} \widehat{\beta}_{\mathrm{F}}-\mathrm{E}\left(\mathrm{X}_{\mathrm{M}}\right)^{\prime} \widehat{\beta}_{\mathrm{M}}
$$

assuming that $\mathrm{E}\left(\beta_{g}\right)=\hat{\beta}_{g}$ and $\mathrm{E}\left(\varepsilon_{g}\right)=0$.

The ultimate objective of our strategy is to estimate and decompose differences in mean wage of female and male workers, and the return of all productivity-relevant factors to wages. Therefore we exploit twofold decomposition approach for our analyses. This approach assumes a non-discriminatory coefficient vector that should be used as counterfactual parameter to determine the contribution of the differences in the groups' explanatory variable to difference in dependent variable. As such, $\bar{X}_{F}$ and $\bar{X}_{M}$ are the mean estimates of $E\left(X_{F}\right)$ and $E\left(X_{M}\right)$, the twofold decomposition of wages difference can then be written as:

$$
\mathrm{R}=\left\{\bar{X}_{F}-\bar{X}_{M}\right\}^{\prime} \widehat{\beta}^{*}+\left\{\bar{X}_{F}^{\prime}\left(\widehat{\beta}_{\mathrm{F}}-\widehat{\beta}^{*}\right)+\bar{X}_{M}^{\prime}\left(\widehat{\beta}^{*}-\widehat{\beta}_{\mathrm{M}}\right)\right\}
$$

Where the first term of the twofold decomposition on the right-hand side, which is given by:

\footnotetext{
${ }^{3}$ Weber \& Wolter (1999) provide a valuable consideration in our modification of the basic Mincerian earning function, particularly in determining gender wage gap and its differential contributing factors and explanatory variables.
} 


$$
Q=\left\{\bar{X}_{F}-\bar{X}_{M}\right\}^{\prime} \widehat{\beta}^{*}
$$

is the explained component which is the part of the wages difference that is represent female and male workers differences in variables, signifying endowment effect. Whereas the second term:

$$
U=\left\{\bar{X}_{F}^{\prime}\left(\widehat{\beta}_{\mathrm{F}}-\widehat{\beta}^{*}\right)+\bar{X}_{M}^{\prime}\left(\widehat{\beta}^{*}-\widehat{\beta}_{\mathrm{M}}\right)\right\}
$$

is the unexplained component, which is the part of the wages difference that represent the absence of differences in the explanatory variables, signifying wage structure effect. Although this component is commonly associated with wage discrimination, it is critical to scrutinize further, since it also capture the underlying effect of unobserved variables. Explicitly, there are non-discriminatory parameter $\left(\square^{*}\right)$ in both decomposition of explained component and unexplained component as in equation (2.6). Oaxaca (1973) originally assumed that discrimination is directed toward only one of the groups (i.e. female workers), so that $\left(\beta^{*}=\beta_{F}\right) \quad\left(\beta^{*}=\beta_{M}\right)$. Accordingly, he described the assumption as index number problem. This index number problem is arguable to some extent and motivated the development of other non-discriminatory parameter ${ }^{4}$.

Among alternative measures of non-discriminatory parameter, we utilize a 'Regression-Compatible Oaxaca-Blinder Decomposition' approach, following Jann (2008) and Fortin (2008) ${ }^{5}$. First, recall estimations based-on equation (2.2.) for each sample of female and male workers group separately. Then, additional estimation established for both groups samples pooled together $(p)$, so equation (2.2.) can be reformulated as:

$$
w_{g}=\beta_{g} X+\varepsilon_{g}, \quad E\left(\varepsilon_{g}\right)=0 \quad g \in(f, m, p)
$$

Similar to Neumark (1988) and Oaxaca \& Ransom (1994), regression-compatible approach considered estimated coefficients of pooled regression $(p)$ as non-discriminatory parameter, so that are $\left(\beta^{*}=\beta_{p}\right)$ is apply for equation (2.6.) and its derivatives. However, Jann (2008) and Fortin (2008) argued that group membership variables should take into account as an additional explanatory variable in the pooled sample estimation. Failing to do so, could inappropriately transferring the unexplained part of the differential into the explained component, leading to omitted variable bias.

Blinder-Oaxaca decomposition not only allow us to analyse an aggregate wage decomposition but also make possible for detail contribution of selected or all explanatory in each part of decomposition. For the explained component $(\mathrm{Q})$, the detail decomposition can be expressed as follow:

$$
\begin{aligned}
& \hat{Q}=\left(\bar{X}_{F}-\bar{X}_{M}\right)^{\prime} \hat{\beta}^{*} \\
&=\left(\bar{X}_{1 F}-\bar{X}_{1 M}\right)^{\prime} \hat{\beta}_{1}^{*}+\left(\bar{X}_{2 F}-\bar{X}_{2 F}\right)^{\prime} \hat{\beta}_{2}^{*}+\cdots+\left(\bar{X}_{P F}-\bar{X}_{P M}\right)^{\prime} \hat{\beta}_{P}^{*}
\end{aligned}
$$

\footnotetext{
${ }^{4}$ In line with mean decomposition, much of the literature suggests that undervaluation of one group results with an overvaluation of the corresponding group (Cotton, 1988).

${ }^{5}$ See Oaxaca \& Ransom (1994) for exercising integrative treatments of alternatives approaches and Jann (2008) for detailed explanation of those non-discriminatory parameter alternatives.
} 
Where $\bar{X}_{1}, \bar{X}_{2}, \ldots, \bar{X}_{P}$ and $\widehat{\beta}_{1}, \widehat{\beta}_{2}, \ldots, \widehat{\beta}_{P}$ are the means of the explanatory and their associated coefficients, whereby the $\mathrm{p}^{\text {th }}$ summand reflects the contribution of the group differences in the $\mathrm{p}^{\text {th }}$ explanatory. As for the unexplained component (U), if $\rho_{P F}=\widehat{\beta}_{\mathrm{PF}}-\hat{\beta}_{P}^{*}$ and $\rho_{P M}=\widehat{\beta}_{\mathrm{PM}}-\hat{\beta}_{P}^{*}$, the detail decomposition can be expressed as follows:

$$
\widehat{U}=\bar{X}_{F}^{\prime} \rho_{F}+\bar{X}^{\prime}{ }_{M} \rho_{M}=\bar{X}_{1 F}^{\prime} \rho_{1 F}+\bar{X}^{\prime}{ }_{1 M} \rho_{1 M}+\bar{X}_{2 F}^{\prime} \rho_{2 F}+\bar{X}_{2 F}^{\prime} \rho_{2 F}+\cdots+\bar{X}_{P F}^{\prime} \rho_{P F}+\bar{X}_{P M}^{\prime} \rho_{P M}
$$

Since unexplained component also captures all of potential effects of differences in unobserved variables, detailed decomposition might not be as straightforward as explained component. In case of dummy explanatory variables, deviation contrast are employed to transform the dummy-variable sets, so that the contribution of categorical variables to the unexplained part of the decomposition is independent of the choice of the base category. In our decomposition, we set the first category as the base of each categorical variable. Our estimation and decomposition are execute within Oaxaca-Blinder Decomposition platform by Jann (2008) using STATA 13.

Further computation are exercised to produce more comparable measures of intergenerational wage gaps and its components. Accordingly, intergenerational wage gap measured in two folds. First as a youth wage gap, measured by mean wages differences of millennials and gen-Xers. Secondly as elderly wage gap, measured by mean wages differences of boomers and gen-Xers. Raw, unadjusted and adjusted wage gap are computed based on the same formulation, i.e.:

$$
g_{e}^{y}=\frac{\left(\overline{w^{C}}-\overline{w^{D}}\right)}{\overline{w^{C}}} \times 100 \%
$$

Where youth wage gap $\left(\mathrm{g}^{\mathrm{y}}\right)$ or elderly wage gap $\left(\mathrm{g}_{\mathrm{e}}\right)$ are percentage differences between mean wage of disadvantaged worker group $\left(\mathrm{w}^{\mathrm{D}}\right)$ and its corresponding group $\left(\mathrm{w}^{\mathrm{C}}\right)$ relatively to its corresponding group $\left(\mathrm{w}^{\mathrm{C}}\right)$. As described above, wage differences decomposed into two fold, explained and unexplained components. Endowment effect (e) and remuneration effect (r), represent consecutively represent by explained and unexplained components, measured by each percentage contribution on wage differences. Following Taniguchi \& Tuwo (2014), wage gap attributable to wage discrimination are calculated as:

$$
\operatorname{Disc}=r_{e}^{y} \times g_{e}^{y}
$$

For analysis, the main variable of interest, is monthly nominal wage, defined as the gross wage structure in cash and in-kind paid to workers at regular intervals, for time worked or work done together with wage structure for time not worked, such as annual vacation, other types of paid leave or holidays ${ }^{6}$. This earnings calculation excludes employer contributions to social security and pension schemes and also the benefits received by workers under these schemes. This nominal wage calculation also excludes severance and termination pay. Additionally, we exercise explanatory variables within each wage differential contributing factors. In line with the outcome variable, minimum wage is defined as the

\footnotetext{
${ }^{6}$ Following the resolution concerning the measurement of employment-related income adopted by the Sixteenth International Conference of Labour Statisticians (October 1998).
} 
regional nominal minimum wage paid on a monthly basis in each of the 511 sub provincial regions in Indonesia based on cost of living standard of each region ${ }^{7}$. Minimum wage set to represent institutional instrument factor of regional labour market.

In individual characteristic, we include age and marital status. We include age to capture its own possible contribution to productivity, i.e. physical strength. Gender dummy variable included as group membership identifier. Within human capital investment factor, education attainment, tenure, vocational and training. Education attainment measured by years of schooling correspond to Indonesian education system. To capture more specific effects on schooling other than years of general schooling, dummy variable of general education and vocational education also included. Furthermore, training also included to capture specialization or investment to develop certain types of knowledge or skill. Training dummy variable differentiate worker with no training, first training and the one with secondary training. We also include tenure as a proxy for on-the-job human capital accumulation, considering that our data set does not explicitly provide personal data on experience in terms of 'time span after schooling'. Quadratic form included to exercise the possibility of diminishing returns of age and tenure. For working condition factor, we included traveling to work variables, measured by daily commuting for working on another regency out of individual's resident area. Hours of work in the previous week also included consider that wages might be sensitive to the length of working hours. We also consider whether or not a worker also has a secondary job. The necessity of controlling for the secondary job arises from the possibility that the main source of earnings is inadequate to meet a family's needs (Dasgupta, 2015). In this working condition factor, dummy variables of urban-rural individual resident area, types of work, and secondary job are also included in estimation.

To examine the contribution occupational choice or occupational segregation in inequality of gender wage gap, dummy variables of formal-informal occupation, nine sectoral categories and eight skilledbased occupational categories. The sectoral categories aims for examine horizontal segregation, while the occupational categories for vertical segregation. After controlling for all productivity-relevant variables, any differential in earnings of two equally productive workers is subject to inefficient behaviour in wage structure, by favouritism or discrimination, i.e. the wage structure effect. Aside from aggregate gender wage decomposition, analyses on sub groups also established to examine the extent of every contributing variables in gender pay gap. The detailed decomposition analysis establish to highlight certain variable within each factors or any other variables that serve certain importance in gender wage gap.

Subgroups decomposition also establish to answer the objectives of this study. We estimate and decompose gender wage gap within each sub groups categorized by marital status and breadwinner

\footnotetext{
${ }^{7}$ Recently, cost of living standard in regional minimum wage determined by decent living need and taking into account cost of 60 items, consumer price index, labour market development, current regional wage, aggregate firms conditions, and national and regional economic trends.
} 
status. Four sub categories based on marital status are decompose, including single, married, divorced, widowed. Six types of income earners in family breadwinner model ala Lewis (2001) might essentially bias to gender equality as they overlook other possibilities, e.g. a female full-time breadwinner or a male full-time family caregiver. As alternative, we examine different categorization of sub samples by distinguish family earners into eight types of breadwinners, i.e.: primary, secondary, tertiary, single earners, single roles, and double roles. The former four breadwinner types are based on family membership of the family earner (i.e. household head, spouse or other family member) and the last two types are based on additional category of the role of household and spouse in the family (i.e. income earner and family carer).

\section{RESULTS}

As a developing country, Indonesia is struggling with inequality in many aspects of development including gender wage inequality in labour market. Despite converging education attainment between female and male workers in recent years, participation of women in the economy is moderately lower compare to men. In 2015, female to male labour participation rate and female to male employment to population ratio are is nearly 60 percent. Thus, more educated women are out of labour market with the unemployment rate of 6.37 percent, higher than male unemployment rate. Many high skilled women working in lower skill job and event take part-time job with female underemployment rate of 8.57 percent (Statistic Indonesia, 2016).

Taking into account education and all other human capital investment variables, persisting gender wage gap are most likely affected by two other factors, family division of labour and occupation segregations. Labour structure by marital status between women and men are similar, around 20 percent being single and around 70 percent being married. Thus family division of labour most likely contribute a certain portion on wage differential between women and men. The first indicators of family division of labour role in labour participation is almost double of female compare to male part-time workers rate. Thus, more women are choose to take part-time jobs in addition to their main role in caring the family.

Table 1. Labour Force Indicators by Gender, Indonesia 2015 (Percent)

\begin{tabular}{|c|c|c|c|c|c|c|}
\hline No. & Indicators & Female & Male & Indicators & Female & Male \\
\hline 1. & Labour participation rate & 48.87 & 82.71 & 14. Married workers by informality* & 100 & 100 \\
\hline 2. & Employment to population & 45.76 & 77.69 & informal sectors & 65.89 & 57.16 \\
\hline 3. & Part-time workers & 31.81 & 15.25 & formal sectors & 34.11 & 42.84 \\
\hline 4. & Underemployment rate & 8.57 & 8.43 & 15. Married workers by Sectors & 100 & 100 \\
\hline 5. & Unemployment rate & 6.37 & 6.07 & agriculture, farming, forestry, etc. & 10.09 & 24.64 \\
\hline \multirow[t]{4}{*}{6.} & Labour education attainment & 100 & 100 & mining \& quarrying & 0.37 & 2.97 \\
\hline & primary education & 31.81 & 32.81 & manufacture industries & 14.14 & 10.94 \\
\hline & secondary education & 41.80 & 53.42 & electricity, gas, \& water supply & 0.12 & 0.64 \\
\hline & tertiary education & 26.39 & 13.76 & constructions & 0.35 & 8.10 \\
\hline \multirow[t]{2}{*}{7.} & Labour by marital status & 100 & 100 & trading, restaurant, etc. & 30.78 & 16.05 \\
\hline & single & 19.09 & 20.78 & transportations, storage, etc. & 0.68 & 10.91 \\
\hline
\end{tabular}

Sustainability Science and Resources, Vol. 1:2, 2021, pp. 38 - 61 


\begin{tabular}{|c|c|c|c|c|c|c|}
\hline & married & 66.36 & 75.51 & finance, real estate \& services & 2.19 & 3.45 \\
\hline & divorced & 5.20 & 1.81 & Social \& community services & 41.29 & 22.29 \\
\hline & widowed & 9.34 & 1.91 & 16. Married workers by Occupations & 100 & 100 \\
\hline 8. & Labour Breadwinner Status & 100 & 100 & legislator, senior off. \& managers & 1.56 & 2.89 \\
\hline & primary BW & 14.43 & 70.42 & professionals & 18.75 & 7.13 \\
\hline & secondary BW & 55.32 & 0.25 & technicians \& ass. professionals & 4.71 & 4.25 \\
\hline & tertiary BW & 28.66 & 28.77 & clerks & 11.63 & 8.45 \\
\hline & non BW & 1.60 & 0.55 & services \& market sales & 28.30 & 13.76 \\
\hline 9. & Active-Workers & 87.15 & 98.67 & skilled agricultural \& fishery & 8.24 & 17.73 \\
\hline 10. & Passive-Workers & 12.42 & 0.57 & craft \& related trades & 9.75 & 11.59 \\
\hline 11. & Family-Carer & 94.93 & 28.50 & plant, machine op. \& assemblers & 2.36 & 13.01 \\
\hline 12. & Single Rolers & 2.26 & 49.00 & elementary occupations & 14.51 & 19.11 \\
\hline 13. & Double Rolers & 56.39 & 19.85 & armed forces & 0.19 & 2.08 \\
\hline
\end{tabular}

*Including unpaid family workers.

Source: Statistics Indonesia (2016) and Sakernas (2015), reproduced.

Wage differential analysis in the first step of our decomposition analyses. The wage regression results for female workers, male workers and pooled group is presented in Table 2. The first panel of the table, present all explanatory variables of individual characteristics factor. Expectantly age and gender have significant role as innate ability determining wage. A positive and statistically significant coefficient of gender group identifier variable in the pooled estimation indicates a significant wage difference, in which male workers earn more than female workers. Our estimation result also show negative significant coefficient of age-squared variables, signifying non-linear relationship between age and wage (i.e. differing ages effect). Thus, the positive relationship between age and wage will only last to a certain point of age and start diminishing afterward. Our further estimate find the turning point is in the middle age of 50's, shortly prior to retirement age. Furthermore, being married more likely to have higher rate of wage than other marital status, i.e. single, divorced and widowed. 
Table 2. Wage Regression on Female, Male and Pooled Sample

\begin{tabular}{|c|c|c|c|c|c|c|}
\hline \multirow{2}{*}{ Variables } & \multicolumn{2}{|c|}{ Female Workers } & \multicolumn{2}{|c|}{ Male Workers } & \multicolumn{2}{|c|}{ Pooled } \\
\hline & Coef. & Std. Err. & Coef. & Std. Err. & Coef. & Std. Err. \\
\hline \multicolumn{7}{|l|}{ Individual characteristics } \\
\hline Age & $0.030 * * *$ & $(0.002)$ & $0.034 * * *$ & $(0.002)$ & $0.032 * * *$ & $(0.001)$ \\
\hline $\mathrm{Age}^{2 \text { a) }}$ & $-0.291 * * *$ & $(0.026)$ & $-0.389 * * *$ & $(0.018)$ & $-0.347 * * *$ & $(0.015)$ \\
\hline Marital status (base: single) & & & & & & \\
\hline married & $0.102 * * *$ & $(0.011)$ & $0.190 * * *$ & $(0.008)$ & $0.139 * * *$ & $(0.006)$ \\
\hline divorced & $0.127 * * *$ & $(0.017)$ & 0.018 & $(0.018)$ & $0.088 * * *$ & $(0.012)$ \\
\hline widowed & $0.046 * * *$ & $(0.016)$ & -0.002 & $(0.018)$ & $0.038 * * *$ & $(0.011)$ \\
\hline Identifier: Gender & - & - & - & - & $0.247 * * *$ & $(0.004)$ \\
\hline \multicolumn{7}{|l|}{ Human capital investment } \\
\hline Years of schooling & $0.053 * * *$ & $(0.001)$ & $0.041 * * *$ & $(0.001)$ & $0.046 * * *$ & $(0.001)$ \\
\hline Tenure & $0.004 * * *$ & $(0.000)$ & $0.002 * * *$ & $(0.000)$ & $0.003 * * *$ & $(0.000)$ \\
\hline Tenure $^{2 \text { a) }}$ & $-0.005 * * *$ & $(0.000)$ & $-0.002 * * *$ & $(0.000)$ & $-0.003 * * *$ & $(0.000)$ \\
\hline Vocational (base: general) & $0.021 *$ & $(0.011)$ & $0.014 * *$ & $(0.007)$ & $0.019 * * *$ & $(0.006)$ \\
\hline Training (base: no training) & & & & & & \\
\hline Primary training & $0.263 * * *$ & $(0.012)$ & $0.230 * * *$ & $(0.009)$ & $0.242 * * *$ & $(0.007)$ \\
\hline Secondary training & $0.455 * * *$ & $(0.017)$ & $0.425 * * *$ & $(0.014)$ & $0.445 * * *$ & $(0.011)$ \\
\hline \multicolumn{7}{|l|}{ Working Conditions } \\
\hline Working hours & $0.007 * * *$ & $(0.000)$ & $0.006 * * *$ & $(0.000)$ & $0.006^{* * *}$ & $(0.000)$ \\
\hline Rural (base: urban) & $-0.095 * * *$ & $(0.007)$ & 0.008 & $(0.005)$ & $-0.033 * * *$ & $(0.004)$ \\
\hline Types of work (base: full time) & & & & & & \\
\hline part time & $-0.240 * * *$ & $(0.011)$ & $-0.147 * * *$ & $(0.008)$ & $-0.202^{* * *}$ & $(0.007)$ \\
\hline under employed & $-0.560 * * *$ & $(0.015)$ & $-0.415^{* * *}$ & $(0.010)$ & $-0.475^{* * *}$ & $(0.009)$ \\
\hline Secondary job (base: primary) & $0.134 * * *$ & $(0.012)$ & $0.101 * * *$ & $(0.007)$ & $0.097 * * *$ & $(0.006)$ \\
\hline Domestic (base: travel to work) & $-0.286^{* * *}$ & $(0.014)$ & $-0.139 * * *$ & $(0.009)$ & $-0.189 * * *$ & $(0.007)$ \\
\hline \multicolumn{7}{|l|}{ Institutional Instrument } \\
\hline ln minimum wage & $0.621 * * *$ & $(0.013)$ & $0.608 * * *$ & $(0.010)$ & $0.613 * * *$ & $(0.008)$ \\
\hline \multicolumn{7}{|l|}{ Occupational Choices } \\
\hline Formal (base: informal) & 0.013 & $(0.010)$ & $-0.127 * * *$ & $(0.006)$ & $-0.079 * * *$ & $(0.005)$ \\
\hline \multicolumn{7}{|l|}{ Occupations (base: LSOM) } \\
\hline professional & $-0.416 * * *$ & $(0.027)$ & $-0.378 * * *$ & $(0.016)$ & $-0.386 * * *$ & $(0.013)$ \\
\hline technicians \& prof. assoc. & $-0.273 * * *$ & $(0.029)$ & $-0.296 * * *$ & $(0.017)$ & $-0.286 * * *$ & $(0.015)$ \\
\hline clerks & $-0.352 * * *$ & $(0.027)$ & $-0.416 * * *$ & $(0.015)$ & $-0.371 * * *$ & $(0.013)$ \\
\hline services \& market sales & $-0.651 * * *$ & $(0.029)$ & $-0.671 * * *$ & $(0.016)$ & $-0.667 * * *$ & $(0.014)$ \\
\hline skilled agricultural \& fishery & $-0.820 * * *$ & $(0.038)$ & $-0.931 * * *$ & $(0.020)$ & $-0.872 * * *$ & $(0.018)$ \\
\hline craft and related trades & $-0.831 * * *$ & $(0.031)$ & $-0.735 * * *$ & $(0.016)$ & $-0.762 * * *$ & $(0.014)$ \\
\hline operator \& assemblers & $-0.385 * * *$ & $(0.035)$ & $-0.630 * * *$ & $(0.016)$ & $-0.580 * * *$ & $(0.015)$ \\
\hline elementary occupations & $-0.704 * * *$ & $(0.028)$ & $-0.813 * * *$ & $(0.015)$ & $-0.775 * * *$ & $(0.014)$ \\
\hline armed forces & 0.108 & $(0.077)$ & $0.042 * *$ & $(0.021)$ & 0.015 & $(0.020)$ \\
\hline \multicolumn{7}{|l|}{ Sectors (base: agriculture) } \\
\hline mining \& quarrying & $0.206 * * *$ & $(0.055)$ & $0.249 * * *$ & $(0.017)$ & $0.257 * * *$ & $(0.016)$ \\
\hline manufacture & $-0.064 * *$ & $(0.026)$ & $-0.119 * * *$ & $(0.013)$ & $-0.123 * * *$ & $(0.012)$ \\
\hline electricity, gas \& water supply & 0.072 & $(0.091)$ & -0.006 & $(0.031)$ & -0.016 & $(0.030)$ \\
\hline constructions & $0.206 * * *$ & $(0.053)$ & $0.052 * * *$ & $(0.014)$ & $0.061 * * *$ & $(0.013)$ \\
\hline trading, hotel \& restaurant & -0.028 & $(0.026)$ & $-0.102 * * *$ & $(0.014)$ & $-0.095 * * *$ & $(0.012)$ \\
\hline transportation \& comm. & 0.007 & $(0.040)$ & $-0.192 * * *$ & $(0.014)$ & $-0.186 * * *$ & $(0.013)$ \\
\hline finance services & 0.019 & $(0.030)$ & $-0.102 * * *$ & $(0.016)$ & $-0.084 * * *$ & $(0.015)$ \\
\hline social \& community services & $-0.276 * * *$ & $(0.024)$ & $-0.286 * * *$ & $(0.013)$ & $-0.291 * * *$ & $(0.011)$ \\
\hline _Cons & $4.013 * * *$ & $(0.202)$ & $4.670 * * *$ & $(0.143)$ & $4.053 * * *$ & $(0.118)$ \\
\hline Number of obs. & \multicolumn{2}{|c|}{58,947} & \multicolumn{2}{|c|}{104,621} & \multicolumn{2}{|c|}{163,568} \\
\hline Prob > F & \multirow{2}{*}{\multicolumn{2}{|c|}{0.000}} & \multicolumn{2}{|c|}{0.000} & \multicolumn{2}{|c|}{0.000} \\
\hline Adj. R-squared & & & \multicolumn{2}{|c|}{0.3278} & 0.36 & \\
\hline
\end{tabular}

a) Age and tenure square normalized by 1000 .

b) $* p<0.1, * * p<0.05$, ***p $<0.01$

In the second panel is all explanatory variables of human capital investment factor. Expectantly years of schooling have positive effect on nominal wage rate, whereas tenure show similar differing effect as age. Vocational education and training also show positive effect on the wage differential. As an institutional instrument, minimum wages show statistically significant roles in wage determination in female worker, male worker and pooled sample groups. As there are both wages of female and male workers above and below minimum wage rates, statistically significant coefficient indicate both 
spillover effect and numeraire effect of minimum wage. All the variables related to working condition also have significant effect on wage. Being full-time worker, in urban area, having a secondary job and traveling to work also have positive effect on wage. Based on occupational choices, working as formal worker as senior officer or manager (LSOM) in mining and quarrying sector giving greater possibility to earn higher wage rate compare to other occupational choice.

The first four pair columns in Table 4 present decomposition of wage differential by marital status and the latter two are decomposition of marriage premiums. Married worker experience the highest gender wage gap as married-female workers earned nearly 30 percent lesser than married-male workers. In contrast, single workers experience the lowest gender wage gap as single-female workers earned 10.23 percent lesser than single-male workers. For married workers, differences in years of schooling and tenure contribute significantly to explained components of gender wage gap. In Table 5, we present decomposition of gender wage differential of primary breadwinner, secondary breadwinner, single earner, and tertiary breadwinner. Within each of primary and secondary breadwinner, we also exercise sub sample of single roles (i.e. breadwinner only) and double roles (i.e. breadwinner and family-carer). Our results show that gender wage gap experienced by all breadwinners, where primary breadwinner experienced the highest and tertiary breadwinner the lowest. Single earner and tertiary breadwinners, with lower rate of wages, experienced relatively lower gender wage rate. Interestingly, despite contribution of human capital factor which is similar to primary breadwinner, being in urban area significantly contribute to gender wage gap and in favour of female workers.

Comparing within each group straightforwardly, the result show that primary breadwinner earned higher rate of wages. The wage rate of double roles primary breadwinners even higher, as well as their wage gap. These findings suggest that taking responsible as family provider do motivate workers for higher rate of wages which in turn also have to deal with higher wage gap. Detailed decomposition revealed that contributing variables within human capital investment factor (i.e. education, tenure, and training) play greater part in explained component of primary breadwinner gender wage gap. While for secondary breadwinner, working condition factor (i.e. working hour, types of job and traveling to work) take the part. 
Table 3. Gender Wage Gap by Marital Status and Marriage Premium Decompositions

\begin{tabular}{|c|c|c|c|c|c|c|c|c|c|c|c|c|}
\hline \multirow[b]{2}{*}{ Variables } & \multicolumn{2}{|c|}{ Single } & \multicolumn{2}{|c|}{ Married } & \multicolumn{2}{|c|}{ Divorced } & \multicolumn{2}{|c|}{ Widowed } & \multicolumn{2}{|c|}{ Married Women } & \multicolumn{2}{|c|}{ Married Men } \\
\hline & Coef. & $\begin{array}{l}\text { Robust } \\
\text { Std. Err. }\end{array}$ & Coef. & $\begin{array}{l}\text { Robust } \\
\text { Std. Err. }\end{array}$ & Coef. & $\begin{array}{l}\text { Robust } \\
\text { Std. Err. }\end{array}$ & Coef. & $\begin{array}{l}\text { Robust } \\
\text { Std. Err. }\end{array}$ & Coef. & $\begin{array}{l}\text { Robust } \\
\text { Std. Err. }\end{array}$ & Coef. & $\begin{array}{l}\text { Robust } \\
\text { Std. Err. }\end{array}$ \\
\hline \multicolumn{13}{|c|}{ Overall Decomposition } \\
\hline Group 1 predicted wage $*$ & $13.741 * * *$ & $(0.009)$ & $13.896 * * *$ & $(0.005)$ & $13.787 * * *$ & $(0.016)$ & $13.610 * * *$ & $(0.013)$ & $13.741 * * *$ & $(0.009)$ & $13.848 * * *$ & $(0.006)$ \\
\hline Group 2 predicted wage* & $13.848^{* * *}$ & $(0.006)$ & $14.252 * * *$ & $(0.003)$ & $13.926 * * *$ & $(0.020)$ & $13.827 * * *$ & $(0.020)$ & $13.896 * * *$ & $(0.005)$ & $14.252 * * *$ & $(0.003)$ \\
\hline Difference & $-0.108 * * *$ & $(0.010)$ & $-0.356^{* * *}$ & $(0.006)$ & $-0.139 * * *$ & $(0.026)$ & $-0.218 * * *$ & $(0.023)$ & $-0.156 * * *$ & $(0.010)$ & $-0.404 * * *$ & $(0.007)$ \\
\hline Explained & $-0.039 * * *$ & $(0.007)$ & $-0.058 * * *$ & $(0.004)$ & $-0.018^{*}$ & $(0.018)$ & $-0.034 * *$ & $(0.017)$ & $-0.039 * * *$ & $(0.007)$ & $-0.058 * * *$ & $(0.004)$ \\
\hline Unexplained & $-0.069 * * *$ & $(0.010)$ & $-0.298^{* * *}$ & $(0.005)$ & $-0.121 * * *$ & $(0.025)$ & $-0.184 * * *$ & $(0.021)$ & $-0.069 * * *$ & $(0.010)$ & $-0.298 * * *$ & $(0.005)$ \\
\hline \multicolumn{13}{|c|}{ Detailed Decomposition } \\
\hline \multicolumn{13}{|l|}{ Explained } \\
\hline \multicolumn{13}{|l|}{ Individual Characteristics } \\
\hline Age & -0.006 & $(0.004)$ & $-0.081 * * *$ & $(0.004)$ & -0.015 & $(0.012)$ & $0.016^{*}$ & $(0.010)$ & $-0.006 * * *$ & $(0.004)$ & $-0.081 * * *$ & $(0.004)$ \\
\hline $\left.\operatorname{Age}^{2} a\right)$ & $-0.007 *$ & $(0.004)$ & $0.073 * * *$ & $(0.004)$ & 0.012 & $(0.012)$ & -0.014 & $(0.011)$ & $-0.007 * * *$ & $(0.004)$ & $0.073 * * *$ & $(0.004)$ \\
\hline \multicolumn{13}{|l|}{ Human Capital Investment } \\
\hline Years of schooling & $0.078 * * *$ & $(0.003)$ & $0.027 * * *$ & $(0.001)$ & 0.002 & $(0.005)$ & $-0.023 * * *$ & $(0.004)$ & $0.078 * * *$ & $(0.003)$ & $0.027 * * *$ & $(0.001)$ \\
\hline Tenure & $-0.003^{*}$ & $(0.002)$ & $-0.044 * * *$ & $(0.002)$ & $-0.029 * * *$ & $(0.008)$ & $-0.034 * * *$ & $(0.009)$ & $-0.003 * * *$ & $(0.002)$ & $-0.044 * * *$ & $(0.002)$ \\
\hline Tenure $^{2}$ a) & $-0.003 * * *$ & $(0.001)$ & $0.015^{* * *}$ & $(0.001)$ & 0.008 & $(0.005)$ & $0.020 * * *$ & $(0.006)$ & $-0.003 * * *$ & $(0.001)$ & $0.015 * * *$ & $(0.001)$ \\
\hline Vocational & -0.00005 & $(0.000)$ & $0.001 * * *$ & $(0.000)$ & 0.001 & $(0.001)$ & -0.000 & $(0.001)$ & $-0.00005^{* *}$ & $(0.000)$ & $0.001 * *$ & $(0.000)$ \\
\hline Training & $0.006 * * *$ & $(0.001)$ & $0.010 * * *$ & $(0.001)$ & $0.008 * * *$ & $(0.003)$ & $0.005^{* * *}$ & $(0.002)$ & $0.006 * * *$ & $(0.001)$ & $0.010 * * *$ & $(0.001)$ \\
\hline \multicolumn{13}{|l|}{ Working conditions } \\
\hline Working hours & $-0.003 * *$ & $(0.001)$ & $-0.026 * * *$ & $(0.001)$ & 0.005 & $(0.003)$ & $-0.008 * *$ & $(0.003)$ & $-0.003 * * *$ & $(0.001)$ & $-0.026 * * *$ & $(0.001)$ \\
\hline Urban & $0.005^{* * *}$ & $(0.001)$ & $0.001 * * *$ & $(0.000)$ & $0.005 * * *$ & $(0.002)$ & $0.004 * * *$ & $(0.001)$ & $0.005 * * *$ & $(0.001)$ & $0.001 * *$ & $(0.000)$ \\
\hline Fulltime & -0.001 & $(0.002)$ & $-0.025 * * *$ & $(0.001)$ & 0.002 & $(0.004)$ & $-0.008 * * *$ & $(0.003)$ & $-0.001 * * *$ & $(0.002)$ & $-0.025 * * *$ & $(0.001)$ \\
\hline Secondary job & $0.001 *$ & $(0.000)$ & $0.007 * * *$ & $(0.001)$ & 0.001 & $(0.001)$ & $0.002 *$ & $(0.001)$ & $0.001 * * *$ & $(0.000)$ & $0.007 * * *$ & $(0.001)$ \\
\hline Travel to work & $0.004 * * *$ & $(0.001)$ & $-0.003 * * *$ & $(0.000)$ & 0.001 & $(0.002)$ & -0.002 & $(0.001)$ & $0.004 * * *$ & $(0.001)$ & $-0.003 * * *$ & $(0.000)$ \\
\hline \multicolumn{13}{|l|}{ Institutional Instrument } \\
\hline Minimum wage & -0.003 & $(0.002)$ & $-0.020 * * *$ & $(0.001)$ & $-0.008 *$ & $(0.004)$ & $-0.021 * * *$ & $(0.004)$ & $-0.003 * * *$ & $(0.002)$ & $-0.020 * * *$ & $(0.001)$ \\
\hline \multicolumn{13}{|l|}{ Occupational Choices } \\
\hline Informality & $-0.013 * * *$ & $(0.001)$ & $0.002 * * *$ & $(0.000)$ & $-0.005 * *$ & $(0.002)$ & 0.002 & $(0.001)$ & $-0.013^{*}$ & $(0.001)$ & $0.002 * * *$ & $(0.000)$ \\
\hline occupation & $0.018 * * *$ & $(0.005)$ & $0.054 * * *$ & $(0.003)$ & $0.035 * *$ & $(0.014)$ & $0.049 * * *$ & $(0.014)$ & $0.018 * * *$ & $(0.005)$ & $0.054 * * *$ & $(0.003)$ \\
\hline Sector & $-0.113 * * *$ & $(0.005)$ & $-0.049 * * *$ & $(0.003)$ & $-0.039 * * *$ & $(0.013)$ & $-0.021 * * *$ & $(0.013)$ & $-0.113 * * *$ & $(0.005)$ & $-0.049 * *$ & $(0.003)$ \\
\hline
\end{tabular}




\begin{tabular}{|c|c|c|c|c|c|c|c|c|c|c|c|c|}
\hline & Coef. & $\begin{array}{c}\text { Robust } \\
\text { Std. Err. }\end{array}$ & Coef. & $\begin{array}{c}\text { Robust } \\
\text { Std. Err. }\end{array}$ & Coef. & $\begin{array}{c}\text { Robust } \\
\text { Std. Err. }\end{array}$ & Coef. & $\begin{array}{c}\text { Robust } \\
\text { Std. Err. }\end{array}$ & Coef. & $\begin{array}{l}\text { Robust } \\
\text { Std. Err. }\end{array}$ & Coef. & $\begin{array}{c}\text { Robust } \\
\text { Std. Err. }\end{array}$ \\
\hline \multicolumn{13}{|l|}{ Unexplained } \\
\hline \multicolumn{13}{|l|}{ Individual Characteristics } \\
\hline Age & -0.015 & $(0.177)$ & -0.214 & $(0.150)$ & 0.855 & $(0.652)$ & -0.776 & $(0.902)$ & -0.015 & $(0.177)$ & -0.214 & $(0.150)$ \\
\hline $\operatorname{Age}^{2}$ a) & 0.013 & $(0.077)$ & $0.204 * * *$ & $(0.077)$ & -0.386 & $(0.338)$ & 0.493 & $(0.499)$ & 0.013 & $(0.077)$ & 0.204 & $(0.077)$ \\
\hline \multicolumn{13}{|l|}{ Human Capital Investment } \\
\hline Years of schooling & $0.225 * * *$ & $(0.038)$ & $0.114 * * *$ & $(0.014)$ & $0.094 *$ & $(0.049)$ & $0.053^{*}$ & $(0.032)$ & $0.225^{*}$ & $(0.038)$ & 0.114 & $(0.014)$ \\
\hline Tenure & $0.055 * * *$ & $(0.018)$ & $0.188 * * *$ & $(0.018)$ & 0.055 & $(0.065)$ & $0.177 * *$ & $(0.086)$ & 0.055 & $(0.018)$ & $0.188 * * *$ & $(0.018)$ \\
\hline Tenure $^{2 \text { a) }}$ & -0.005 & $(0.006)$ & $-0.041 * * *$ & $(0.009)$ & -0.003 & $(0.033)$ & -0.077 & $(0.051)$ & $-0.005 * * *$ & $(0.006)$ & $-0.041 * * *$ & $(0.009)$ \\
\hline Vocational & -0.004 & $(0.007)$ & $0.018 * * *$ & $(0.007)$ & 0.039 & $(0.029)$ & -0.031 & $(0.039)$ & $-0.004 * * *$ & $(0.007)$ & $0.018 * * *$ & $(0.007)$ \\
\hline Training & 0.024 & $(0.026)$ & $-0.025 * * *$ & $(0.009)$ & -0.011 & $(0.077)$ & 0.030 & $(0.067)$ & $0.024 * * *$ & $(0.026)$ & $-0.025^{*}$ & $(0.009)$ \\
\hline \multicolumn{13}{|l|}{ Working conditions } \\
\hline Working hours & $-0.194 * * *$ & $(0.040)$ & $0.102 * * *$ & $(0.019)$ & -0.104 & $(0.083)$ & 0.067 & $(0.076)$ & $-0.194 * * *$ & $(0.040)$ & $0.102 * * *$ & $(0.019)$ \\
\hline Urban & $0.030 * * *$ & $(0.004)$ & $0.008 * * *$ & $(0.001)$ & 0.005 & $(0.004)$ & 0.000 & $(0.001)$ & $0.030 * * *$ & $(0.004)$ & 0.008 & $(0.001)$ \\
\hline Fulltime & $0.083 * * *$ & $(0.016)$ & $0.048 * * *$ & $(0.007)$ & $0.055^{*}$ & $(0.030)$ & -0.025 & $(0.026)$ & $0.083 * * *$ & $(0.016)$ & $0.048 * *$ & $(0.007)$ \\
\hline Secondary job & 0.030 & $(0.022)$ & $0.012 *$ & $(0.007)$ & $0.081 * *$ & $(0.033)$ & 0.037 & $(0.025)$ & 0.030 & $(0.022)$ & 0.012 & $(0.007)$ \\
\hline Travel to work & $-0.031 * * *$ & $(0.010)$ & $-0.062 * * *$ & $(0.007)$ & -0.030 & $(0.038)$ & -0.042 & $(0.049)$ & $-0.031 *$ & $(0.010)$ & $-0.062 * * *$ & $(0.007)$ \\
\hline \multicolumn{13}{|l|}{ Institutional Instrument } \\
\hline Minimum wage & -0.362 & $(0.500)$ & 0.277 & $(0.288)$ & -2.187 & $(1.396)$ & -0.690 & $(1.298)$ & $-0.362 * * *$ & $(0.500)$ & $0.277 * * *$ & $(0.288)$ \\
\hline \multicolumn{13}{|l|}{ Occupational Choices } \\
\hline Informality & $0.058 * * *$ & $(0.014)$ & $0.017 * * *$ & $(0.002)$ & -0.001 & $(0.004)$ & -0.005 & $(0.008)$ & 0.058 & $(0.014)$ & $0.017 * * *$ & $(0.002)$ \\
\hline occupation & -0.020 & $(0.017)$ & $-0.016^{*}$ & $(0.008)$ & 0.019 & $(0.040)$ & 0.016 & $(0.051)$ & $-0.020 * * *$ & $(0.017)$ & $-0.016 * * *$ & $(0.008)$ \\
\hline Sector & -0.017 & $(0.020)$ & -0.026 & $(0.016)$ & -0.001 & $(0.065)$ & 0.061 & $(0.052)$ & $-0.017 * * *$ & $(0.020)$ & $-0.026 * * *$ & $(0.016)$ \\
\hline Constant & 0.060 & $(0.512)$ & $-0.902 * * *$ & $(0.298)$ & 1.399 & $(1.455)$ & 0.529 & $(1.392)$ & $0.060 * * *$ & $(0.512)$ & $-0.902 * * *$ & $(0.298)$ \\
\hline Number of obs. & & 32,308 & & 118,938 & & 4,905 & & 7,417 & & 50,410 & & 100,836 \\
\hline Group 1 mean wage (IDR) & & $1,357,745$ & & $1,759,781$ & & $1,456,038$ & & $1,291,691$ & & $1,357,745$ & & $1,441,672$ \\
\hline Group 2 mean wage (IDR) & & $1,441,672$ & & $2,244,505$ & & $1,574,612$ & & $1,447,790$ & & $1,759,781$ & & $2,244,505$ \\
\hline Unadjusted wage gap & & $5.82 \%$ & & $21.60 \%$ & & $7.53 \%$ & & $10.78 \%$ & & $22.85 \%$ & & $35.77 \%$ \\
\hline Group 1 predicted wage (IDR) & & 927,789 & & $1,084,305$ & & 971,630 & & 813,890 & & 928,198 & & $1,033,023$ \\
\hline Group 2 predicted wage (IDR) & & $1,033,478$ & & $1,547,452$ & & $1,117,026$ & & $1,011,728$ & & $1,083,817$ & & $1,547,266$ \\
\hline Adjusted wage gap (AWG) & & $10.23 \%$ & & $29.93 \%$ & & $13.02 \%$ & & $19.55 \%$ & & $14.36 \%$ & & $33.24 \%$ \\
\hline Wage structure effect & & $63.78 \%$ & & $83.67 \%$ & & $87.00 \%$ & & $84.50 \%$ & & $69.23 \%$ & & $46.78 \%$ \\
\hline $\mathrm{ATD}^{\mathrm{b})}$ & & $6.52 \%$ & & $25.04 \%$ & & $11.32 \%$ & & $16.54 \%$ & & $9.94 \%$ & & $15.55 \%$ \\
\hline
\end{tabular}

a) Age and tenure square normalized by 1000.

b) ATD: Adjusted wage gap attributable to discrimination

c) Robust standard errors in parentheses, *** $\mathrm{p}<0.01, * * \mathrm{p}<0.05, * \mathrm{p}<0.1$ 
Table 4. Breadwinners Models and Gender Wage Gap Decompositions

\begin{tabular}{|c|c|c|c|c|c|c|c|c|c|c|c|c|c|c|c|c|}
\hline \multirow[b]{2}{*}{ Variables } & \multicolumn{2}{|c|}{ Primary } & \multicolumn{2}{|c|}{ Primary SR } & \multicolumn{2}{|c|}{ Primary DR } & \multicolumn{2}{|c|}{ Secondary } & \multicolumn{2}{|c|}{ Secondary SR } & \multicolumn{2}{|c|}{ Secondary DR } & \multicolumn{2}{|c|}{ Single Earners } & \multicolumn{2}{|c|}{ Tertiary } \\
\hline & Coef. & $\begin{array}{c}\text { Robust } \\
\text { Std. Err. }\end{array}$ & Coef. & $\begin{array}{l}\text { Robust } \\
\text { Std. Err. }\end{array}$ & Coef. & $\begin{array}{c}\text { Robust } \\
\text { Std. Err. }\end{array}$ & Coef. & $\begin{array}{c}\text { Robust } \\
\text { Std. Err. }\end{array}$ & Coef. & $\begin{array}{l}\text { Robust } \\
\text { Std. Err. }\end{array}$ & Coef. & $\begin{array}{c}\text { Robust } \\
\text { Std. Err. }\end{array}$ & Coef. & $\begin{array}{l}\text { Robust } \\
\text { Std. Err. }\end{array}$ & Coef. & $\begin{array}{l}\text { Robust } \\
\text { Std. Err. }\end{array}$ \\
\hline \multicolumn{17}{|c|}{ Overall Decomposition } \\
\hline Predicted female wage & $13.91 * * *$ & $(0.03)$ & $14.23 * * *$ & $(0.09)$ & $13.87 * * *$ & $(0.033)$ & $13.92 * * *$ & $(0.01)$ & $14.27 * * *$ & $(0.03)$ & $13.91 * * *$ & $(0.01)$ & $13.67 * * *$ & $(0.01)$ & $13.73 * * *$ & $(0.01)$ \\
\hline Predicted male wage & $14.28 * * *$ & $(0.00)$ & $14.28 * * *$ & $(0.00)$ & $14.28 * * *$ & $(0.006)$ & $14.16^{* * * *}$ & $(0.06)$ & $14.28 * * *$ & $(0.06)$ & $13.87 * * *$ & $(0.12)$ & $13.85^{* * *}$ & $(0.02)$ & $13.89 * * *$ & $(0.01)$ \\
\hline Difference & $-0.37 * * *$ & $(0.03)$ & -0.05 & $(0.09)$ & $-0.41 * * *$ & $(0.034)$ & $-0.25 * * *$ & $(0.06)$ & -0.01 & $(0.07)$ & 0.03 & $(0.12)$ & $-0.19 * * *$ & $(0.03)$ & $-0.17 * * *$ & $(0.01)$ \\
\hline Explained & $-0.09^{* * *}$ & $(0.02)$ & 0.08 & $(0.05)$ & $-0.14 * * *$ & $(0.019)$ & $-0.12 * * *$ & $(0.04)$ & 0.06 & $(0.06)$ & 0.04 & $(0.06)$ & $-0.04 * *$ & $(0.017)$ & $-0.05 * * *$ & $(0.01)$ \\
\hline Unexplained & $-0.27 * * *$ & $(0.02)$ & $-0.13 * *$ & $(0.07)$ & $-0.27 * * *$ & $(0.026)$ & $-0.13^{* * *}$ & $(0.05)$ & -0.07 & $(0.06)$ & -0.01 & $(0.10)$ & $-0.14 * * *$ & $(0.02)$ & -0.11 & $(0.01)$ \\
\hline \multicolumn{17}{|c|}{ Detailed Decomposition } \\
\hline \multicolumn{17}{|c|}{ Explained Components } \\
\hline \multicolumn{17}{|c|}{ Individual Characteristics } \\
\hline Age & $-0.028 * * *$ & $(0.010)$ & 0.014 & $(0.029)$ & $-0.021^{* *}$ & $(0.010)$ & -0.014 & $(0.021)$ & -0.001 & $(0.007)$ & 0.024 & $(0.039)$ & $0.022^{* *}$ & $(0.011)$ & $0.023 * * *$ & $(0.004)$ \\
\hline $\mathrm{Age}^{2 \mathrm{a})}$ & $0.026^{* * *}$ & $(0.010)$ & -0.014 & $(0.030)$ & $0.019 *$ & $(0.010)$ & 0.019 & $(0.017)$ & 0.002 & $(0.007)$ & -0.013 & $(0.033)$ & $-0.030 * *$ & $(0.012)$ & $-0.027 * * *$ & $(0.003)$ \\
\hline \multicolumn{17}{|c|}{ Human Capital Investment } \\
\hline Years of schooling & $-0.021 * * *$ & $(0.007)$ & 0.025 & $(0.021)$ & $-0.049 * * *$ & $(0.008)$ & -0.007 & $(0.014)$ & $0.052^{* *}$ & $(0.022)$ & -0.002 & $(0.026)$ & $-0.030 * * *$ & $(0.005)$ & $0.065^{* * *}$ & $(0.002)$ \\
\hline Tenure & $-0.031 * * *$ & $(0.006)$ & 0.002 & $(0.017)$ & $-0.041^{* * *}$ & $(0.007)$ & $0.035^{*}$ & $(0.019)$ & $0.057^{* *}$ & $(0.025)$ & 0.044 & $(0.035)$ & $-0.020 * *$ & $(0.008)$ & $0.003^{*}$ & $(0.002)$ \\
\hline Tenure $^{2 \text { a) }}$ & $0.008^{* * *}$ & $(0.002)$ & -0.005 & $(0.008)$ & $0.011^{* * *}$ & $(0.004)$ & $-0.014 *$ & $(0.008)$ & -0.019 & $(0.013)$ & -0.018 & $(0.015)$ & $0.010^{*}$ & $(0.006)$ & $-0.006 * * *$ & $(0.001)$ \\
\hline Vocational & $0.001 * *$ & $(0.000)$ & -0.001 & $(0.001)$ & $0.003 * * *$ & $(0.001)$ & $0.003^{*}$ & $(0.002)$ & 0.001 & $(0.002)$ & 0.005 & $(0.004)$ & 0.0002 & $(0.000)$ & 0.002 & $(0.000)$ \\
\hline Training & 0.005 & $(0.003)$ & 0.003 & $(0.008)$ & $-0.006^{* * *}$ & $(0.003)$ & $0.029 * * *$ & $(0.004)$ & $0.021 * * *$ & $(0.006)$ & $0.031 * * *$ & $(0.008)$ & 0.003 & $(0.002)$ & $0.008 * * *$ & $(0.001)$ \\
\hline \multicolumn{17}{|l|}{ Working conditions } \\
\hline Working hours & $-0.015^{* * *}$ & $(0.003)$ & -0.001 & $(0.008)$ & $-0.012^{* * *}$ & $(0.004)$ & $-0.047 * * *$ & $(0.008)$ & $-0.032 * *$ & $(0.013)$ & $-0.026^{*}$ & $(0.015)$ & $-0.006^{*}$ & $(0.003)$ & $-0.014 * * *$ & $(0.001)$ \\
\hline Urban & 0.002 & $(0.000)$ & 0.002 & $(0.000)$ & 0.002 & $(0.001)$ & -0.003 & $(0.002)$ & 0.006 & $(0.005)$ & $-0.007 * *$ & $(0.004)$ & $0.006 * * *$ & $(0.002)$ & $0.004 * * *$ & $(0.001)$ \\
\hline Fulltime & $-0.019 * * *$ & $(0.004)$ & -0.005 & $(0.010)$ & $-0.018^{* * *}$ & $(0.004)$ & $-0.041^{* * *}$ & $(0.009)$ & -0.013 & $(0.011)$ & -0.018 & $(0.020)$ & -0.005 & $(0.003)$ & $-0.013 * * *$ & $(0.002)$ \\
\hline Secondary job & $0.006^{* * *}$ & $(0.001)$ & $0.007 * * *$ & $(0.003)$ & $0.010^{* * *}$ & $(0.002)$ & 0.004 & $(0.003)$ & 0.002 & $(0.007)$ & 0.003 & $(0.005)$ & $0.002 * *$ & $(0.001)$ & $0.001 * * *$ & $(0.000)$ \\
\hline Travel to work & $-0.004 * * *$ & $(0.001)$ & 0.002 & $(0.003)$ & $-0.005^{* * *}$ & $(0.001)$ & $-0.015^{* * *}$ & $(0.005)$ & -0.006 & $(0.006)$ & -0.011 & $(0.008)$ & -0.001 & $(0.001)$ & $0.002 * * *$ & $(0.001)$ \\
\hline \multicolumn{17}{|l|}{ Institutional Instrument } \\
\hline Minimum wage & $-0.034 * * *$ & $(0.004)$ & 0.009 & $(0.013)$ & $-0.019 * * *$ & $(0.005)$ & $-0.037 * * *$ & $(0.009)$ & 0.001 & $(0.011)$ & -0.004 & $(0.015)$ & $-0.009 * *$ & $(0.004)$ & $-0.008 * * *$ & $(0.002)$ \\
\hline \multicolumn{17}{|l|}{ Occupational Choices } \\
\hline Informality & $0.014 * * *$ & $(0.002)$ & 0.003 & $(0.006)$ & $0.013^{* * *}$ & $(0.003)$ & 0.002 & $(0.001)$ & -0.002 & $(0.006)$ & 0.002 & $(0.001)$ & 0.002 & $(0.001)$ & $-0.007 * * *$ & $(0.001)$ \\
\hline occupation & $0.022 * * *$ & $(0.008)$ & 0.076 & $(0.026)$ & -0.011 & $(0.009)$ & 0.020 & $(0.016)$ & $0.093^{* * *}$ & $(0.028)$ & $0.060^{* *}$ & $(0.028)$ & $0.032^{* *}$ & $(0.013)$ & $0.016^{* * *}$ & $(0.004)$ \\
\hline sector & $-0.028^{* * *}$ & $(0.004)$ & $-0.037 * * *$ & $(0.010)$ & $-0.011 * *$ & $(0.005)$ & $-0.048^{* * *}$ & $(0.011)$ & $-0.101 * * *$ & $(0.029)$ & $-0.031^{*}$ & $(0.016)$ & $-0.019 *$ & $(0.011)$ & $-0.100 * * *$ & $(0.004)$ \\
\hline
\end{tabular}




\begin{tabular}{|c|c|c|c|c|c|c|c|c|c|c|c|c|c|c|c|c|}
\hline \multirow[b]{2}{*}{ Variables } & \multicolumn{2}{|c|}{ Primary } & \multicolumn{2}{|c|}{ Primary SR } & \multicolumn{2}{|c|}{ Primary DR } & \multicolumn{2}{|c|}{ Secondary } & \multicolumn{2}{|c|}{ Secondary SR } & \multicolumn{2}{|c|}{ Secondary DR } & \multicolumn{2}{|c|}{ Single Earners } & \multicolumn{2}{|c|}{ Tertiary } \\
\hline & Coef. & $\begin{array}{c}\text { Robust } \\
\text { Std. Err. }\end{array}$ & Coef. & $\begin{array}{c}\text { Robust } \\
\text { Std. Err. }\end{array}$ & Coef. & $\begin{array}{c}\text { Robust } \\
\text { Std. Err. }\end{array}$ & Coef. & $\begin{array}{c}\text { Robust } \\
\text { Std. Err. }\end{array}$ & Coef. & $\begin{array}{c}\text { Robust } \\
\text { Std. Err. }\end{array}$ & Coef. & $\begin{array}{c}\text { Robust } \\
\text { Std. Err. }\end{array}$ & Coef. & $\begin{array}{c}\text { Robust } \\
\text { Std. Err. }\end{array}$ & Coef. & $\begin{array}{c}\text { Robust } \\
\text { Std. Err. }\end{array}$ \\
\hline \multicolumn{17}{|l|}{$\begin{array}{l}\text { Unexplained Components } \\
\text { Individual Characteristics }\end{array}$} \\
\hline Age & $-1.358^{*}$ & $(0.726)$ & 0.602 & $(2.278)$ & -1.205 & $(0.788)$ & 0.459 & $(1.302)$ & -1.550 & (1.444) & 2.417 & $(2.898)$ & -0.550 & $(0.905)$ & -0.149 & $(0.143)$ \\
\hline $\mathrm{Age}^{2}$ a) & $0.643^{*}$ & $(0.372)$ & -0.293 & $(1.168)$ & 0.593 & $(0.403)$ & -0.189 & $(0.664)$ & 0.890 & $(0.755)$ & -0.860 & $(1.359)$ & 0.361 & $(0.491)$ & 0.061 & $(0.065)$ \\
\hline \multicolumn{17}{|l|}{ Human Capital Investment } \\
\hline Years of schooling & 0.029 & $(0.056)$ & -0.176 & $(0.159)$ & 0.031 & $(0.061)$ & 0.014 & $(0.137)$ & 0.137 & $(0.163)$ & -0.342 & $(0.333)$ & 0.054 & $(0.035)$ & $0.166 * * *$ & $(0.030)$ \\
\hline Tenure & $0.157 * * *$ & $(0.074)$ & -0.037 & $(0.228)$ & $0.138^{*}$ & $(0.081)$ & -0.128 & $(0.152)$ & -0.173 & $(0.192)$ & 0.142 & $(0.313)$ & 0.134 & $(0.084)$ & $0.046^{* * * *}$ & $(0.016)$ \\
\hline Tenure $^{2 \text { a) }}$ & $-0.061^{*}$ & $(0.037)$ & 0.036 & $(0.103)$ & -0.061 & $(0.040)$ & $0.137 *$ & $(0.077)$ & 0.149 & $(0.100)$ & 0.034 & $(0.112)$ & -0.067 & $(0.048)$ & 0.004 & $(0.006)$ \\
\hline Vocational & 0.053 & $(0.033)$ & 0.008 & $(0.061)$ & 0.053 & $(0.038)$ & 0.070 & $(0.057)$ & $-0.118^{* * *}$ & $(0.070)$ & $0.308^{* * *}$ & $(0.109)$ & 0.005 & $(0.038)$ & -0.003 & $(0.006)$ \\
\hline Training & -0.026 & $(0.048)$ & 0.199 & $(0.135)$ & -0.036 & $(0.052)$ & -0.024 & $(0.118)$ & $-0.156^{* *}$ & $(0.066)$ & $-0.514 * * *$ & $(0.180)$ & 0.039 & $(0.058)$ & -0.016 & $(0.022)$ \\
\hline \multicolumn{17}{|l|}{ Working conditions } \\
\hline Working hours & 0.129 & $(0.086)$ & 0.065 & $(0.243)$ & 0.126 & $(0.094)$ & 0.279 & $(0.174)$ & 0.529 & $(0.225)$ & -0.002 & $(0.333)$ & 0.040 & $(0.078)$ & $-0.064 *$ & $(0.033)$ \\
\hline Urban & $0.011^{* * *}$ & $(0.004)$ & 0.023 & $(0.019)$ & $0.011 *$ & $(0.005)$ & $0.027 *$ & $(0.014)$ & 0.018 & $(0.014)$ & 0.039 & $(0.043)$ & 0.0003 & $(0.001)$ & $0.022 * * *$ & $(0.002)$ \\
\hline Fulltime & $-0.071 * *$ & $(0.032)$ & -0.032 & $(0.082)$ & $-0.080 * *$ & $(0.034)$ & -0.134 & $(0.099)$ & -0.139 & $(0.117)$ & -0.331 & $(0.230)$ & -0.016 & $(0.025)$ & $0.073 * * *$ & $(0.012)$ \\
\hline Secondary job & 0.034 & $(0.032)$ & 0.084 & $(0.105)$ & 0.033 & $(0.033)$ & -0.056 & $(0.061)$ & -0.021 & $(0.079)$ & -0.162 & $(0.106)$ & $0.042 *$ & $(0.025)$ & $0.033^{* *}$ & $(0.016)$ \\
\hline Travel to work & -0.020 & $(0.051)$ & $-0.218 *$ & $(0.113)$ & 0.010 & $(0.054)$ & -0.015 & $(0.052)$ & -0.012 & $(0.060)$ & 0.063 & $(0.138)$ & -0.008 & $(0.049)$ & $-0.036 * * *$ & $(0.009)$ \\
\hline \multicolumn{17}{|l|}{ Institutional Instrument } \\
\hline Minimum wage & $2.936^{* *}$ & $(1.479)$ & 2.752 & $(4.722)$ & 2.362 & $(1.611)$ & -2.070 & $(2.898)$ & -2.248 & $(3.201)$ & -3.819 & $(5.295)$ & -1.804 & $(1.362)$ & 0.211 & $(0.416)$ \\
\hline \multicolumn{17}{|l|}{ Occupational Choices } \\
\hline Informality & 0.002 & $(0.001)$ & 0.023 & $(0.020)$ & 0.003 & $(0.002)$ & -0.011 & $(0.015)$ & $-0.020^{*}$ & $(0.022)$ & 0.034 & $(0.034)$ & -0.004 & $(0.007)$ & 0.049 & $(0.008)$ \\
\hline occupation & $-0.120 * * *$ & $(0.033)$ & -0.116 & $(0.076)$ & $-0.104 * * *$ & $(0.034)$ & -0.009 & $(0.044)$ & $0.012 *$ & $(0.053)$ & -0.019 & $(0.085)$ & 0.079 & $(0.048)$ & -0.012 & $(0.013)$ \\
\hline Sector & -0.004 & $(0.048)$ & $0.135^{* *}$ & $(0.066)$ & -0.040 & $(0.081)$ & 0.028 & $(0.047)$ & -0.072 & $(0.082)$ & 0.049 & $(0.077)$ & 0.020 & $(0.047)$ & -0.022 & $(0.018)$ \\
\hline Constant & $-2.605 *$ & $(1.539)$ & -3.183 & $(4.715)$ & -2.104 & $(1.690)$ & 1.490 & $(3.030)$ & 2.710 & $(3.351)$ & 2.956 & $(5.739)$ & 1.530 & $(1.441)$ & $-0.475^{* * *}$ & $(0.431)$ \\
\hline Number of obs. & \multicolumn{2}{|c|}{70,583} & \multicolumn{2}{|c|}{49,612} & \multicolumn{2}{|c|}{20,971} & \multicolumn{2}{|c|}{32,943} & \multicolumn{2}{|c|}{1,369} & \multicolumn{2}{|c|}{31,574} & \multicolumn{2}{|r|}{7,686} & \multicolumn{2}{|c|}{46,178} \\
\hline Mean female wage (IDR) & \multirow{2}{*}{\multicolumn{2}{|c|}{$\begin{array}{l}1,805,549 \\
2,315,030\end{array}$}} & \multirow{2}{*}{\multicolumn{2}{|c|}{$\begin{array}{l}2,609,412 \\
2,314,740\end{array}$}} & & & 1,80 & 8,486 & 2,475 & 5,198 & 1,783 & 3,447 & & $1,356,249$ & & 63,085 \\
\hline Mean male wage (IDR) & & & & & 2,31 & 5,744 & 2,29 & 97,988 & 2,548 & 8,597 & 1,668 & 8,081 & & $1,510,339$ & & 97,136 \\
\hline Unadjusted gender wage gap & & $2.01 \%$ & & $2.73 \%$ & & $.36 \%$ & & $1.30 \%$ & & $2.88 \%$ & & $5.92 \%$ & & $10.20 \%$ & & $8.95 \%$ \\
\hline Predicted female wage (IDR) & 1,09 & 6,902 & 1,510 & 0,574 & 1,05 & 4,946 & 1,10 & 77,926 & 1,573 & 3,794 & 1,093 & 3,616 & & 860,269 & & 16,209 \\
\hline Predicted male wage (IDR) & 1,59 & 1,202 & 1,591 & 1,202 & 1,59 & 1,202 & 1,41 & 5,509 & 1,586 & 36,435 & 1,060 & 0,234 & & $1,036,127$ & & 80,571 \\
\hline Adjusted gender wage gap & & $1.06 \%$ & n.s. & & & $.70 \%$ & & $1.73 \%$ & n.s. & & n.s. & & & $16.97 \%$ & & $15.21 \%$ \\
\hline Wage structure effect & & $3.49 \%$ & n.s. & & & $.72 \%$ & & $2.98 \%$ & n.s. & & n.s. & & & $77.39 \%$ & & n.s. \\
\hline ATD $^{b)}$ & & $2.83 \%$ & n.s. & & & $.49 \%$ & & $1.51 \%$ & n.s. & & n.s. & & & $13.13 \%$ & & n.s. \\
\hline
\end{tabular}

a) Age and tenure square normalized by 1000

b) ATD: Adjusted wage gap attributable to discrimination

c) n.s.: statistically non-significant wage differential, i.e. insufficient for measuring gender wage gap and components contribution including treatment effect.

d) Robust standard errors in parentheses, $* * * \mathrm{p}<0.01, * * \mathrm{p}<0.05, * \mathrm{p}<0.1$ 


\section{DISCUSSIONS}

Walton (2019) pictured above conditions as the double burden of Indonesian women. Our further analysis based-on breadwinner theory, support the view. We categorize breadwinner status of individual based on family membership and working status. Our finding show 70.42 percent of men are primary breadwinner in the family, i.e. being household head and main provider of the family. While 55.32 percent of women are secondary breadwinner. Whereas our calculation show more nearly 95 percent women are mainly family-carer, compare to nearly 30 percent of men for the same role. It is a preliminary indication of traditional family division of labour incidence in Indonesia, where men are family's primary income earner and women are family's primary care giver with the twist of also being family's income earner.

Those reality lead to other issues in Indonesia dual labour market, i.e. occupational segregation and gender wage gap. Labour distribution across sectors in Table 1 show that women and men are crowding up in difference sectors. By Informality, higher portion of women as well men work in informal jobs. The reasons behind the portion are possibly diverge. Women work in informal jobs for the intention of maintaining family-caring whist in the same time supporting family income. Whereas men work in informal jobs for other potential reasons, e.g. overcrowding formal sectors, limited formal jobs creation, or pursuing higher rate of income. Based on sectoral distribution, larger portion of married-female workers are in trading, restaurant and accommodation sector and social and community services. Whereas larger portion of married-male workers are in agricultural sector. Accordingly, larger portions of married women works as professionals, services and market sales. Whereas larger portions of married men works as skilled agricultural and fishery workers.

Workers distributions above show relative female and male dominated sectors where other problems also might contribute to gender wage gap, i.e. undervaluation of female dominated job. The overall preliminary indication of dual labour market in Indonesia above served as our starting point to examine further the extent of gender wage inequality and the contributing factors with the focus on marital status, family division of labour and the role of minimum wage. In the next section, we elaborate and scrutinize the magnitude, variant and attributes of adjusted gender wage gap and extending further to consider marital status and family division of labours.

Our estimation result (Table 3) show that years of schooling contribute positively in favour of female workers, indicate that female pursuance of higher education has actually paying off. While in early year of tenure might in favour of married-male worker, at certain years of tenure married-female taking over the wage differences. Additionally, occupation choices contribute the most of gender wage gap. Differences in sectoral job contribute in favour of married-male workers, whereas differences in occupational job contribute in favour of married-female workers. These finding indicate while male stand out across horizontal job (sectors), female might actually in higher position within vertical job 
(occupations). Despite some variables in explained component of wage differences are partially in favour female workers (i.e. partially contribute to closing gender wage gap), unexplained components contribute to wage differential to higher rate. Our decomposition result show that being previously or presently married, experienced higher possibility of wage discrimination as wage structure effect contribute more than 80 percent of gender wage gap. Although it is not necessarily associate with marriage wage gap.

Our findings also provide alternative perspective of analysis by comparing predicted wage between single workers and married workers within each gender group. Marital status positively associated with productivity of male workers, which in turn results in male marriage premium (De Hoon, Keizer \& Dykstra, 2015; De Linde Leonard, \& Stanley, 2015). On the contrary, marital status is negatively associated with productivity of female workers, which in turn results in female marriage penalty (Nwaka et al., 2016; Blau \& Khan, 2016). It is argued that married-female workers have lower productivity, e.g. due to less effort to stay at work, work schedule and travelling constraint and lack of enthusiasm to be promoted to a more demanding position. Interestingly our results not only add similar empirical evidence of a male marriage premium, but in the other hand contrasting evidence of a female marriage premium.

While decomposition result show female actually gain wage marriage premium rather than penalty as traditional view ala Becker (1981) will expect. Despite the same positive contribution of year of education, tenure and occupation in the explained component as married-male workers does, convergence effect of marital status on wage between female and male workers. Being married had elevated the importance of earning higher wage, lead to more productive and pursuance of better job (Gorman, 2000; Waite \& Gallagher, 2000; and Lewis, 2001). However our decomposition also show that married-male earned wage marriage premium significantly higher not only to single-male workers but even to married female. Similar with Blau \& Kahn (1992, 2001, 2016) and Waldfogel (1998), our findings emphasize the substantial contribution of marital status to gender wage gap, even after controlling for productivity related variables. Thus, married-female workers no longer face wage penalty, but still have to deal with gender pay gap. Our findings similar with Bear \& Glick (2017) that concluded family caregiver penalty can become a breadwinner premium if female present themselves as family breadwinners.

In regards of family division of labour, our estimation results highlight interesting results. Difference nature of gender wage gap between those types of breadwinner. Workers with higher rate of human capital investment most likely earned higher rate of wage and take the responsibility as primary breadwinner. While spouses, taking responsibility as secondary breadwinners, depend on the advantages of working conditions factors. Accordingly, our results suggest primary breadwinner women have to deal with differences in human capital factor, whereas secondary breadwinner women with working condition factor. As for unexplained component of wage differences, for single earners, 
only secondary job remain statistically significant and in favour of female workers. This finding imply that wage of single parent women, with secondary jobs, manage to surpass equal productive single parent male. In case of tertiary breadwinner, the contribution proportion of explanatory variables are moderately similar with single workers expectantly. While most of explanatory variables no longer significantly contribute in all other sub samples of married workers. Except for occupational choice and types of job for a lesser portion. These finding suggest that glass ceiling effect does exist, married working women have to deal will with inequality of pay to married men of equal productive and equal position.

\section{CONCLUSIONS}

Gender wage gap is important indicator on the achievement of Sustainable Development Goals, particularly gender equality (Goal 5) and decent work and economic growth (Goal 8). As initial step of gender wage differential decomposition, our wage determinant analysis show that most of selected variables in individual characteristics, human capital investment, working conditions, institutional instrument and occupational choices are statistically significant, including gender as identifier variable and marital status as focus of interest in this study. Our wage decomposition analyses, the centre of this study, revealed several interesting results. Our wage decomposition result suggest that gender wage gap all present in almost all sub samples. Aggregately, gender wage gap present regardless of any stage of working history or priority of activities, and even in married women preferred jobs. According to marital status, married worker earned highest wage rate, but also experience the highest discrimination effect. In addition to those finding, our decomposition analysis also revealed that married working women no longer experienced wage penalty, as traditional family division of labour would argue, but actually gain wage premium. However, married working women wage premium is considerably lower that married working men premium.

Disaggregated based on breadwinner models, our decomposition analyses revealed that primary breadwinner with double roles earned the highest wage rate, highest gender wage gap and highest wage discrimination. These findings suggest that taking responsible as family provider and family care do motivate workers for higher rate of wages, but also have to deal with higher wage gap and discrimination as well. It appeared that in our cases, despite the incidences of double roles married working women are considerably higher than men did, gender inequality of pay and wage discriminant persisted. While the role of regional minimum wage as current nominal institutional labour market instrument still trivial, there are open possibility for making it an effective policy instrument toward more equal pay.

Additionally, policy options toward more equal pay are empirically abundance. They are ranged from less obligatory indirect actions (i.e. sharing information and awareness, capacity building and 
empowering collective action) to obligatory straightforward policies (i.e. improved monitoring, implementing incentives for compliance and targeted labour inspection). Improving human capital investment in all aspects will certainly remain a key factor in achieving equal pay as a whole. Given the gravity of achieving equal pay, extending in future research to include intertemporal and interregional analysis of gender equality of pay will be essential in achieving this goal. Further studies considering other factors related to family division of labour are also recommended. 


\section{REFERENCES}

Ahmed, S., \& McGillivray, M. (2015). Human capital, discrimination, and the gender wage gap in Bangladesh. World Development, 67, 506-524.

Aigner, D. J., \& Cain, G. G. (1977). Statistical theories of discrimination in labour markets. ILR Review, 30(2), 175-187.

Anderson, T., Forth, J., Metcalf, H., \& Kirby, S. (2001). The gender wage gap. Women and Equality Unit (Cabinet Office), London.

Arrow, K. J. (1973). The theory of discrimination.

Bargain, O., \& Kwenda, P. (2014). The informal sector wage gap: New evidence using quantile estimations on panel data. Economic Development and Cultural Change, 63(1), 117-153.

Bear, J. B., \& Glick, P. (2017). Breadwinner bonus and caregiver penalty in workplace rewards for men and women. Social Psychological and Personality Science, 8(7), 780-788.

Beblo, M., Beninger, D., Heinze, A., \& Laisney, F. (2003). Measuring selectivity-corrected gender wage gaps in the EU.

Becker, G. S., (1962). Investment in Human Capital: A Theoretical Analysis," Journal of Political Economy 70, no. 5, Part 2: 9-49.

Becker, G. S., (1964). Human capital: A theoretical and empirical analysis, with special reference to schooling. NY: National Bureau of Economic Research.

Beer, S. H., \& Barringer, R. E. (Eds.). (1970). The state and the poor. Winthrop Publishers.

Bertola, G., Blau, F. D., \& Kahn, L. M. (2001). Comparative analysis of labor market outcomes: lessons for the US from international long-run evidence (No. w8526). National bureau of economic research.

Blau, F. D., \& Kahn, L. M. (1992). Race and gender pay differentials (No. w4120). National Bureau of Economic Research.

Blau, F. D., \& Kahn, L. M. (2017). The gender wage gap: Extent, trends, and explanations. Journal of Economic Literature, 55(3), 789-865.

Blau, F. D., Brummund, P., \& Liu, A. Y. H. (2013). Trends in occupational segregation by gender 1970-2009: Adjusting for the impact of changes in the occupational coding system. Demography, 50(2), 471-492.

Blau, F. D., Kahn, L.M. (2016). The gender wage gap: Extent, trends, and explanations (No. w21913). National Bureau of Economic Research.

Blau, F.D., Ferber M.A., Winkler A.E. (2010). The Economics of Women, Men and Work, 6th ed., Prentice Hall, Boston, MA.

Blinder, A. S. (1973). Wage discrimination: reduced form and structural estimates. Journal of Human resources, 436-455.

Bradbury, K. L. (2000). Rising tide in the labor market: to what degree do expansions benefit the disadvantaged?. New England Economic Review, 3-34.

Brown, C., \& Corcoran, M. (1997). Sex-based differences in school content and the male-female wage gap. Journal of Labour Economics, 15(3), 431-465.

Bulow, J. I., \& Summers, L. H. (1986). A theory of dual labour markets with application to industrial policy, discrimination, and Keynesian unemployment. Journal of labour Economics, 4(3, Part 1), 376-414.

Charles, C. Z. (2003). The dynamics of racial residential segregation. Annual review of sociology, 29(1), 167-207.

Cotton, J. (1988). On the decomposition of wage differentials. The review of economics and statistics, 236-243. 
Creighton, C. (1999). The rise and decline of the 'male breadwinner family' in Britain. Cambridge Journal of Economics, 23(5), 519-541.

Dasgupta, S., Bhula-or, R., \& Fakthong, T. (2015). Earnings differentials between formal and informal employment in Thailand (No. 994896403402676). International Labour Organization.

De Hoon, Sean; Keizer, Renske; Dykstra, Pearl (2015) : The male marriage wage premium in crossnational perspective, LIS Working Paper Series, No. 642.

De Linde Leonard, M., \& Stanley, T. D. (2015). Married with children: What remains when observable biases are removed from the reported male marriage wage premium? Labour Economics, $33,72-80$.

Doeringer, P. B., \& Piore, M. J. (1971). 1971Internal Labor Markets and Manpower Analysis. Lexington, MA: Heath.

Eagly, A. H. (1997). Sex differences in social behavior: comparing social role theory and evolutionary psychology.

Fortin, N., Lemieux, T., \& Firpo, S. (2011). Decomposition methods in economics. Handbook of labour economics, 4, 1-102.

Fuchs, H. (2016). Gender gaps in the labour market: wage and occupational segregation. State of the Nation Report 2015.

Gorman, E. H. (2000). Marriage and money: The effect of marital status on attitudes toward pay and finances. Work and Occupations, 27(1), 64-88.

Gould, E., Schieder, J., \& Geier, K. (2016). What is the gender pay gap and is it real?. Economic Policy Institute.

Hallward-Driemeier, M., Rijkers, B., \& Waxman, A. (2015). Can minimum wages close the gender wage gap? Evidence from Indonesia. Review of Income and Wealth.

He, G., \& Wu, X. (2017). Marketization, occupational segregation, and gender earnings inequality in urban China. Social Science Research, 65, 96-111.

Heinze, A., Beninger, D., Beblo, M., \& Laisney, F. (2003). Measuring selectivity-corrected gender wage gaps in the EU (No. 03-74). ZEW Discussion Papers.

Hirsch, B., König, M., \& Möller, J. (2013). Is there a gap in the gap? Regional differences in the gender wage gap. Scottish Journal of Political Economy, 60(4), 412-439.

Huffman, M. L., King, J., \& Reichelt, M. (2017). Equality for whom? Organizational policies and the gender gap across the German earnings distribution. ILR Review, 70(1), 16-41.

International Labour Organization (ILO), (2016). Minimum Wage Policy Guide, Geneva: Switzerland.

International Labour Organization (ILO), 2014. Minimum Wage Systems, General Survey of the reports on the Minimum Wage Fixing Convention, 1970 (No. 131), and the Minimum Wage Fixing Recommendation, 1970 (No. 135), Geneva: Switzerland.

Jann, B. (2008). The Blinder-Oaxaca decomposition for linear regression models. The Stata Journal, 8(4), 453-479.

Jovanovic, B. (1979). Job matching and the theory of turnover. Journal of political economy, 87(5, Part 1), 972-990.

Jurajda, Š. (2003). Gender wage gap and segregation in enterprises and the public sector in late transition countries. Journal of comparative Economics, 31(2), 199-222.

Leuze, K., \& Strauß, S. (2016). Why do occupations dominated by women pay less? How 'femaletypical'work tasks and working-time arrangements affect the gender wage gap among higher education graduates. Work, employment and society, 30(5), 802-820.

Lewis, J. (1992). Gender and the development of welfare regimes. Journal of European social policy, 2(3), 159-173.

Lewis, J. (2001). The decline of the male breadwinner model: Implications for work and care. Social Politics: International Studies in Gender, State \& Society, 8(2), 152-169. 
Lim, M. (2015). Cohort and Gender Differences and the Marriage Wage Premium: Findings from the NLSY79 and the NLSY97.

Mihăilă, R. (2016). Female labor force participation and gender wage discrimination. Journal of Research in Gender Studies, 6(1), 262-268.

Mincer, J. (1962). Labour force participation of married women: A study of labour supply. In Aspects of labour economics (pp. 63-105). Princeton University Press.

Mincer, J. (1958). Investment in human capital and personal income distribution. Journal of political economy, 66(4), 281-302.

Mincer, J. (1974). Schooling, Experience, and Earnings. Human Behavior \& Social Institutions No. 2.

Mincer, J., \& Polachek, S. W. (1974). Family investments in human capital: Earnings of women. Journal of political Economy, 82(2, Part 2), S76-S108.

Ndamsa, D. T., Njong, M. A., Baye, F. M., \& Youyem, J. (2015). Investigating the role of male advantage and female disadvantage in explaining the discrimination effect of the gender pay gap in the Cameroon labour market. Oaxaca-Ransom decomposition approach. EuroEconomica, 34(1).

Nwaka, I. D., Guven-Lisaniler, F., \& Tuna, G. (2016). Gender wage differences in Nigerian self and paid employment: Do marriage and children matter?. The Economic and Labour Relations Review, 27(4), 490-510.

Oaxaca, R. (1973). Male-female wage differentials in urban labour markets. International economic review, 693-709.

Oaxaca, R. L., \& Ransom, M. R. (1994). On discrimination and the decomposition of wage differentials. Journal of econometrics, 61(1), 5-21.

Oelz, M., Olney, S., \& Tomei, M. (2013). Equal pay: An introductory guide. Geneva: International Labour Office.

Ortiz-Ospina, E., \& Roser, M. (2018). Economic Inequality by Gender. Our World in Data, Our World in Data, 13.

Paglin, M., \& Rufolo, A. M. (1990). Heterogeneous human capital, occupational choice, and malefemale earnings differences. Journal of Labour Economics, 8(1, Part 1), 123-144.

Parry, B. R., \& Segalo, P. (2017). Eating Burnt Toast: The Lived Experiences of Female Breadwinners in South Africa. Journal of International Women's Studies, 18(4), 182-196.

Perales, F. (2013). Occupational sex-segregation, specialized human capital and wages: evidence from Britain. Work, Employment and Society, 27(4), 600-620.

Petersen, T., Penner, A. M., \& Høgsnes, G. (2014). From motherhood penalties to husband premia: The new challenge for gender equality and family policy, lessons from Norway. American Journal of Sociology, 119(5), 1434-1472.

Plasman, R., \& Sissoko, S. (2004). Comparing apples with oranges: Revisiting the gender wage gap in an international perspective, IZA Discussion Paper No. 1449.

Reich, M., Gordon, D. M., \& Edwards, R. C. (1973). A theory of labour market segmentation, The American Economic Review, 63(2), 359-365.

Schultz, T. W. (1960). Capital formation by education. Journal of political economy, 68(6), 571-583.

Schultz, T. W. (1961). Investment in human capital. The American economic review, 1-17.

Sissoko, S. (2007). Wage inequalities in Europe: influence of gender and family status: a series of empirical essays.

Stanley, T. D., \& Jarrell, S. B. (1998). Gender wage discrimination bias? A meta-regression analysis. Journal of Human Resources, 947-973.

Statistic Indonesia, (2016). Potret Ketimpangan Gender dalam Ekonomi, Statistik Gender Tematik, (Portrait of Gender Inequality in the Economy, Thematic Gender Statistics). 
Sugiyarto, G., \& Endriga, B. A. (2008). Do minimum wages reduce employment and training?.

Suleman, F., \& Figueiredo, M. D. C. (2018). Wage differentials within a female-dominated occupation: Domestic workers in informal and flexible jobs in Portugal. International Labour Review, 157(1), 129-152.

Taniguchi, K., \& Tuwo, A. (2014). New Evidence on the Gender Wage Gap in Indonesia.

Waite, L., \& Gallagher, M. (2000). The case for marriage: Why married.

Waldfogel, J. (1998). Understanding the" family gap" in pay for women with children. The Journal of Economic Perspectives, 12(1), 137-156.

Walton, K. (2019). 'Doing it all': Indonesian Women's Women Double Burden, Al-Jazeera.

Weber, B., \& Wolter, S. (1999). Wages and human capital: evidence from Switzerland. Returns to human capital in Europe.

Weichselbaumer, D., \& Winter-Ebmer, R. (2005). A meta-analysis of the international gender wage gap. Journal of Economic Surveys, 19(3), 479-511.

World Economic Forum, (2015), The Global Gender Gap Report 2015, Geneva: World Economic Forum.

Xiu, L., \& Gunderson, M. (2015). Occupational segregation and the gender earnings gap in China: devils in the details. International Journal of Manpower, 36(5), 711-732.

Sustainability Science and Resources (SSR) is jointly published by the Indonesian Forestry Certification Cooperation (IFCC), in collaboration with Millennium Resource Alternatives (MRA) LLC and Sustainable Development Indonesia (SDI). All articles are published in full open access, freely and permanently available online without registration restrictions or subscription charges, immediately upon publication. Authors are the copyright holders of articles published in SSR, but by publishing in this journal they have agreed to grant the right to use, reproduce and or disseminate their articles to any third party. All articles published in SSR are licensed under the terms of the Creative Commons Attribution 4.0 International License. 